\title{
The Effect of Blended Learning Web Course Type With WhatsApp Media On The Critical Thinking Ability Of Elementary
}

\author{
Linda Kusumawati $^{1}$, Mubiar Agustin ${ }^{2}$, Yani Fitriyani ${ }^{3}$ \\ \{lindakusmawati@upi.edu1,mubiar@upi.edu², yanifitriyani@upi.edu $\left.{ }^{3}\right\}$ \\ Primary Education, Universitas Pendidikan Indonesia, Bandung, Indonesia ${ }^{1,3}$, Department of Early \\ Childhood Education, Universitas Pendidikan Indonesia, Bandung ${ }^{2}$
}

\begin{abstract}
This study aims to determine the effect of Blended Learning Course Web type with WhatsApp Media on The Critical Thinking Ability of Elementary Students. The study was conducted to obtain an overview of critical thinking skills in of Civic Education. The subjects of this study were 39 students of Class VI. The type of this research is a preexperimental study with One-Shot Case Study design. The technique of Data analysis used statistical tests with One Sample t-test at the $95 \%$ level of trust. The results showed that the value of tcount $>$ ttable is $4,970>2,024$, and the value of sig. (2-tailed) $<0.05$, it means that there is an influence of Blended Learning on the Web Course type with WhatsApp Media on the Creative Thinking ability of Elementary Students.
\end{abstract}

Keywords: Blended Learning, Critical Thinking, Whatsapp.

\section{Introduction}

Knowledge and technology is something that cannot be separated from human life. Technology is developing so rapidly that it causes the information which is obtained can be received quickly. This development directly affects various aspects of human life, such as politics, economic culture and even education [1]. Education is one of the sectors that cannot be separated from the development of science and technology. Education is the sector that is most responsible for responding to the challenges of the time. In this case, the government answers the challenge has been stated in the attachment of Permendikbud No 21 Tahun 2016 about Basic and secondary Education Content Standards describes the scope of skill competencies, which include creative thinking, productive, critical, independent, collaborative thinking and communication in clear language, systematic, logical, and critical [2].

Related to the demand of curriculum, critical thinking skills are needed in the midst of knowledge and technology development. Critical thinking is a method of thinking which is very important for someone to of critical thinking skill of students. The educator who don't teach their students to think at a higher level usually only apply the conventional learning model [3]. From the statement, it is clearly explained that learning method which is applied in class can influence the development of critical thinking of students. Suana and friend said that if the teacher applied conventional method, the students hard to obtain higher thinking skills level [4]. From the explanation above, the teacher should do a variety of innovative learning one of them is by applying an interesting and fun learning method to improve critical thinking skills students. 
The learning method that is used by teacher is one of factors which is support ability of students thinking [4]. Especially in the midst development of advanced age, science and technology progress should be used in the learning process both online and offline, or by combining online and conventional (face to face) learning method so that the learning process can be done anywhere without being obstructed by distance or time [5]. One of the methods that can be applied is blended learning, the blended learning method is effective at fostering critical thinking skills and independence of students [6]. A blended learning method which is carried out through e-learning without combining conventional learning is called the web course type blended learning method [7]. This web course type blended learning method can be used by teachers when the learning process not allow face to face so that the learning can be carried out by elearning [8]. Thinking is a process that is carried out systematically in order to find a truth to build confidence gained in a factual and realistic [9]. Critical thinking is a way of thinking that becomes a person's intellectual ability to solve problems in the right way based on proper knowledge [10]. Therefore, we can conclude that critical thinking is a mindset which is carried out based on the rules derived from the fact. The indicators of critical thinking skills refer to Ennis [11] those are: (1)Focus, (2) Reason, (3) Inference, (4) Situation, (5) Clarity, and (6) Overview.

Blended learning is a learning method that can be used to combine learning process conventionally by online-based learning. The advantage of this method is the learning process is not only done by face to face in the classroom but also learning process can be done outside classroom without being tied to the distance and time by taking advantage the technology [12]. Blended learning is a learning process that is carried out by combining face to face learning process with e-learning method, it has to use media and it is accompanied by theories that support the learning process [13]. There are three basic stages in implementing blended learning which refers to ITC learning that is expressed by Grant Ramsay [14] those are : (1) seeking of information, it is by seeking information from various available sources both online or offline that are relevant, valid, content reliability and academic clarity. In this case the teacher is a facilitator for facilitating the students. (2) Acquisition of information, individually or in groups, the students cooperate to comprehend and then interpret so they can communicate base on available source. (3) And synthesizing of knowledge, that is constructing knowledge through assimilation process and accommodation start from the results of analysis,discussion, and formulation of conclusion from obtaining information. Haughey [15] suggest there are three methods in the development of studying blended learning those are (1) Web course method, this method is a learning method using the internet for educational purpose, where the students and the teacher are completely separated by distance and face to face process are not carried out in this learning. All learning activity is completely carried out via internet. (2) The web centric course method, the learning process is carried by combining between offline and online learning. Some of the material is delivered via face to face and some of them via internet, therefore the learning process is complemented each other. And (3) Web enhanced method is a learning method by taking advantage of internet for improving the quality of studying in the class, therefore in this case the teacher are required to understand the internet for learning needs as a tool for searching information and convey the information which is obtained via the web [16].

Some studies have stated that application of blended learning can improve critical thinking skills. blended learning method via WhatsApp can improve critical thinking and problem solving skills [4]. WhatsApp is one of effective media that is used to foster critical thinking attitude to elementary students [17]. The results showed that the average college student learning interest before blended learning was 66.70. While the results of the average score of interest in college student after being given learning by utilizing blended learning, which is 85.48 . Thus, 
there is an increased interest in learning with an average of 18.78 [18]. However, the study of blended learning web course type via WhatsApp is still relatively rare used in elementary school especially in Civic Education subject. Therefore the aim of this study is for determining the effect of study method blended learning web course type by using WhatsApp media with the critical thinking ability of elementary students on the Civic Education subject in class.

\section{Methodology}

The approach used in this research is quantitative research with the type of pre-experimental design One-Shot Case Study to determine students' critical thinking skills in the Citizenship Education subject. The One-Shote Case Study design is a design in which there is no control group in the study, students are only given treatment after that it is observed by giving posttest questions. The independent variable in the study is the blended learning model with the web course type with Whatsaap media, while the dependent variable is the student's critical thinking ability. The instrument used in the research was critical thinking test questions. The research subjects were students of class VI-B SDN Kencana Indah I, Rancaekek District, Bandung Regency with 39 students. The research data were obtained from the results of discussions through WhatsApp and critical thinking questions given to students. The hypothesis of this research is the critical thinking ability of grade IV students who learn with the blended learning model Web Course type > 80.The data analysis technique used is in the form of the One sample t-test to determine the effect of the Web Course type blended learning model with whatsapp media on thinking skills. critical students.

\section{Result and Discussion}

The learning method which is developed in this study is a blended learning method with a web course type, where all about learning is only carried out online by using Whatsapp media for the Civic Education subject of elementary. Stages in implementing blended learning (1) seeking of information, In this study, because of the study subjects were elementary students, the materials were provided by the teacher were sending learning videos as studied material. The media which are used in this learning process is whatsapp group. (2) Acquisition of information, in group or individually the students cooperates to understand and then interpret so they can re communicate based on available sources. In this study, the materials were provided by the teacher because the target of study is elementary students. The teacher provided video that the students should been learned in whatsapp group and then individually the students were given a space to discuss and they should give their opinion via whatsapp group. (3) Synthesizing of knowledge, Synthesizing of knowledge, that is constructing knowledge by assimilation process and accommodation opposite from analysis result, discussion and formulation of conclusion from obtaining information. At this stage, the students sent discussion result and conclusion from information which obtained by students, here the students were given questions according to the indicators of critical thinking which related to the video has been given. After that, the students wrote the answers from the questions which is sent via whatsapp. 


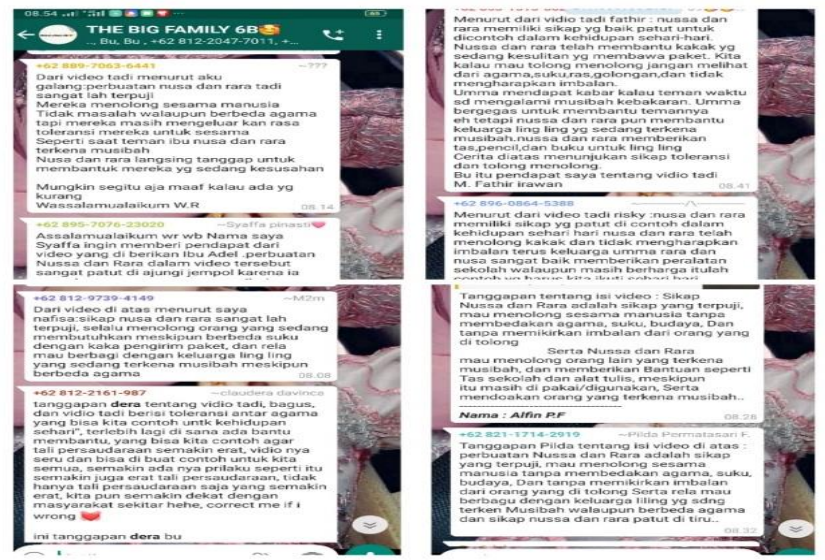

Fig 2. Discussion via whatsapp

The discussion result showed that after applied blended learning method web course type, with whatsapp media, there is an influence critical thinking skills as an indicator which is suggested by Ennis. The instrument of the critical thinking skills kind of testing posttes question which showed that blended learning method web course type of media influenced to the student's critical thinking skills. This was indicated by acquisition of the student's average score that is bigger than before using blended learning method. The result of the student's critical thinking skills test is presented in table 1.

Table 1. Critical Thinking Skills

\begin{tabular}{ccccc}
\hline \multicolumn{5}{c}{ Critical thinking skills } \\
\hline $\begin{array}{c}\text { Kind } \\
\text { of test }\end{array}$ & $\begin{array}{c}\text { Minimum } \\
\text { score }\end{array}$ & $\begin{array}{c}\text { Maximum } \\
\text { score }\end{array}$ & average & $\begin{array}{c}\text { Standard } \\
\text { deviation }\end{array}$ \\
\hline $\begin{array}{c}\text { Post } \\
\text { Tes }\end{array}$ & 72 & 100 & 85,33 & 6,702 \\
\hline
\end{tabular}

\subsection{Normality Testing}

Normality test is used to determine whether the data are distributed or not. The normality is used as required for testing One Sample t-test for testing a distributed data is normal or not, it will be carried out at the end of learning or at the end of the test. That is when the treatment is done by giving posttes question. The results of normality test are presented in table 2 .

Table 2. Normality Test

\begin{tabular}{ccccc}
\hline & Statistik & Df & Sig & Ket. \\
\hline Blended Learning & 90 & 39 & 0,082 & Normal \\
\hline
\end{tabular}

Bases on the calculation result of normality tests by using SPSS version 22 as shown in the table above, it can be concluded that the posttes question are normally distributed and can be continued for testing One Sample t-Test, because the requirement for testing One sample t-test is the data must be normally distributed. 


\subsection{Normality Testing}

The data which were obtained from the study result. They were analyzed by using data analysis of hypothesis testing one sample $t$ test. The result of the analysis is presented on the table bellow

Table 3. One Sampel t-test

\begin{tabular}{lcccccc}
\hline & \multicolumn{6}{c}{ Test Value = 80 } \\
\cline { 2 - 7 } & T & Df & $\begin{array}{c}\text { Sig (2- } \\
\text { tailed) }\end{array}$ & $\begin{array}{c}\text { Mean } \\
\text { Differe } \\
\text { nce }\end{array}$ & \multicolumn{2}{c}{$\begin{array}{c}\text { 95\% Confidence } \\
\text { Interval of the } \\
\text { Difference }\end{array}$} \\
\cline { 5 - 8 } & & & & 5.333 & 3.16 & 7.51 \\
\hline $\begin{array}{l}\text { Blended } \\
\text { learning }\end{array}$ & 4.970 & 38 & 000 & $50 w e r$ & Upper \\
\hline
\end{tabular}

Based on the calculation result by using SPSS version 22, the result of analysis one sample t-tes showed Sig=0,000 it means the value Sig,0,05 it means $\mathrm{H}_{1}$ accepted. The results of the study are consistent with the study [19] blended learning method can increase student motivation and learning achievement in thematic learning, it was shown that there was an average increase in learning motivation by 56,50 and the learning achievement by 57,00 . Similar to the study result [20] who said that "the findings indicate that blended learning was more effective than traditional learning. That is, students in the experimental group not only performed those in the control group in oral proficiency, but they also exhibited higher learning motivation'. We can conclude from the study that there were an effect of blended learning web course type, with whatsapp media of the critical thinking skills of grade VI elementary students. This is shown by the result of analysis t test (One sample t-tes) at the $95 \%$ confidence level, it is obtained $t_{\text {hitung }}>t_{\text {tabel }}$ is $4.970>2,024$ therefofre $\mathrm{H}_{\mathrm{o}}$ is rejected and $\mathrm{H}_{1}$ is accepted.

\section{References}

[1] A. Akbar and N. Noviani, "Tantangan Dan Solusi Dalam Perkembangan Teknologi Pendidikan Di Indonesia," Pros. Semin. Nas. Pendidik. Progr. Pascasarj. Univ. Pgri Palembang, pp. 999-1015, 2019.

[2] "Permendikbud," p. 8, 2016, doi: 10.5151/cidi2017-060.

[3] L. D. Noma, B. A. Prayitno, and Suwarno, "PBL Untuk Meningkatkan Kemampuan Berpikir Tingkat Tinggi Siswa Kelas X SMA,” Bioedukasi, vol. 9, no. 2, pp. 62-66, 2016, doi: 10.1364/OL.36.003374.

[4] W. Suana, M. Raviany, and F. Sesunan, "Blended Learning Berbantuan Whatsapp: Pengaruhnya Terhadap Kemampuan Berpikir Kritis Dan Kemampuan Pemecahan Masalah," Gravity J. Ilm. Penelit. dan Pembelajaran Fis., vol. 5, no. 2, pp. 37-45, 2019, doi: 10.30870/gravity.v5i2.4990.

[5] E. Farida and H. D. Surjono, "Implementation of Blended Learning to Improve Fifth Graders' Learning Participation," Atl. Press 3rd Int. Conf. Curr. Issues Educ. (ICCIE 2018) Implement., vol. 326, no. Iccie 2018, pp. 192-205, 2019, doi: 10.2991/iccie-18.2019.35.

[6] N. B. Haka, L. Anggita, B. S. Anggoro, and A. Hamid, "Pengaruh Blended Learning Berbantukan Google Classroom Terhadap Keterampilan Berpikir Kreatif Dan Kemandirian Belajar Peserta Didik," Edu Sains J. Pendidik. Sains Mat., vol. 8, no. 1, pp. 1-12, 2020, doi: 10.23971/eds.v8i1.1806.

[7] R. Phungsuk, C. Viriyavejakul, and T. Ratanaolarn, "Development of a problem-based learning model via a virtual learning environment,” Kasetsart J. Soc. Sci., vol. 38, no. 3, pp. 297-306, 2017, doi: 10.1016/j.kjss.2017.01.001 
[8] J. E. Prescott, K. Bundschuh, E. R. Kazakoff, and P. Macaruso, "Elementary school-wide implementation of a blended learning program for reading intervention," J. Educ. Res., vol. 111, no. 4, pp. 497-506, 2018, doi: 10.1080/00220671.2017.1302914.

[9] Y. Fitriyani and N. Supriatna, "Efektivitas Penggunaan Model Pembelajaran Kooperatif Tipe Number Head Together (NHT), Teams Games Tournament (TGT) dan Course Review Horay (CRH) Terhadap Kemampuan Berfikir Kritis (Studi Eksperimental pada Mata Pelajaran Ilmu Sosial Kelas V Di Gugus 3 Kec,” Univ. Pendidik. Indones., 2019.

[10] B. Cahyono, "Analisis Ketrampilan Berfikir Kritis Dalam Memecahkan Masalah Ditinjau Perbedaan Gender," Aksioma, vol. 8, no. 1, pp. 50-64, 2017.

[11] A. Fridanianti, H. Purwati, and Y. H. Murtianto, "Analisis Kemampuan Berpikir Kritis Dalam Menyelesaikan Soal Aljabar Kelas Vii Smp N 2 Pangkah Ditinjau Dari Gaya Kognitif Reflektif Dan Kognitif Impulsif," AKSIOMA J. Mat. dan Pendidik. Mat., vol. 9, no. 1, p. 11, 2018, doi: 10.26877/aks.v9i1.2221.

[12] J. Abbas, J. Aman, M. Nurunnabi, and S. Bano, "The impact of social media on learning behavior for sustainable education: Evidence of students from selected universities in Pakistan," Sustain., vol. 11, no. 6, pp. 1-23, 2019, doi: 10.3390/su11061683.

[13] D. N. Wardani, A. J. E. Toenlioe, and A. Wedi, "Daya Tarik Pembelajaran Di Era 21 Dengan Blended Learning," J. Kaji. Teknol. Pendidik., vol. 1, no. 1, pp. 13-18, 2018.

[14] Y. Maya, "Penggunaan Blended Lerninng Pada Pembelajaran Era Industri 4.0," J. Pendidik. Bhs. dan Sastra Indones., vol. 4, no. 2, pp. 31-38, 2020.

[15] Y. Hendarita, "Model Pembelajaran Blended Learning."

[16] A. Hershkovitz, M. A. Elhija, and D. Zedan, "Whatsapp Is The Message: Out Of-Class Communication, Student-Teacher Relationship, And Classroom Environment," J. Inf. Technol. Educ. Res., vol. 18, pp. 63-95, 2019, doi: https://doi.org/10.28945/4183.

[17] S. N. Masitoh, I. D. Yuliyanti, U. D. A. Lestari, and C. Z. Fiftriyah, "Model Pembelajaran Berbasis Blended Learning Melalui Media Whatsapp Dalam Menumbuhkan Critical Thingking Pada Siswa Sd," Pros. FKIP Univ. Jember, pp. 115-1120, 2018.

[18] F. Inggriyani, A. R. Hamdani, and T. Dahlan, "Minat Belajar Mahasiswa dengan Menggunakan Blended Learning melalui Google Classroom pada Pembelajaran Konsep Dasar Bahasa Indonesia SD," PEMBELAJAR J. Ilmu Pendidikan, Keguruan, dan Pembelajaran, vol. 3, no. 1, p. 28, 2019, doi: 10.26858/pembelajar.v3i1.8649.

[19] S. Firdaus, W. Isnaeni, and Ellianawati, "Motivation and Learning Achievement of Primary Students in Theme-Based Learning using Blended Learning Model," J. Prim. Educ., vol. 7, no. 3, pp. 324-331, 2018.

[20] S. Wichadee, "A Development of the Blended Learning Model Using Edmodo for Maximizing Students ' Oral Proficiency and Motivation,” iJET, vol. 12, no. 2, pp. 137-154, 2017. 